\author{
Cadernos de \\ ESTUDOS LINGUIISTICOS - (59.2), Campinas, pp. 333-359 - mai./ago. 2017
}

\title{
LÍNGUA DE ESPECIALIDADE DA PESCA É METÁFORA CONCEPTUAL?
}

\author{
CRISTIANE FERNANDES MOREIRA* \\ (UFBA)
}

\begin{abstract}
RESUMO: O objeto de estudo refere-se aos termos técnicos da pesca artesanal, cujos conceitos são construídos por metáforas conceptuais. Tem como objetivo tecer considerações acerca do fenômeno da metáfora conceptual a partir da TMC (Teoria da Metáfora Conceptual), proposta por Lakoff e Johnson e da ciência que se preocupa em descrever os discursos especializados nas áreas de atividade, a Terminologia, notando que toda profissão possui vocabulário próprio, um glossário que permite comunicação mais efetiva entre os que trabalham em determinada área de conhecimento humano. Trata-se de uma proposta de estudo que relaciona teoria e empiria. Uma das hipóteses é a de que o polo linguagem e pensamento interage na produção das metáforas presentes no vocabulário dos pescadores e na estrutura léxico-conceptual da linguagem, e estabelece relações entre as unidades lexicais, a partir da rede ontológica mais geral. A temática faz uso do método de categorização de efeitos prototípicos e tem como base aplicações de inquéritos linguísticos com pessoas que trabalham na pesca daquela comuna. O corpus é constituído por textos orais. Para tanto, empregam-se a análise de corpus (corpus analysis), em que se explora o fenômeno particular de interesse; a metodologia com base no uso e o PIM (Processamento de Identificação da Metáfora). A coleta e análise dos dados seguem o exemplo da análise por protótipos. Os principais achados revelam que há existência de dois planos: o plano conceptual (que relaciona conceitos) e o plano da expressão (as palavras que são usadas para exprimir esses conceitos) para demonstrar que a metáfora não é aleatória, mas se baseia na relação entre conceitos próximos ou distantes, na rede radial de conceitos. É esperado que uma das principais contribuições deste trabalho para o campo seja a aplicação do modelo da metáfora conceptual sobre a natureza dos mecanismos cognitivos nos termos técnicos de uma língua de especialidade.

Palavras-chave: metáfora conceptual; cognição; língua de especialidade.
\end{abstract}

ABSTRACT: The object of study refers to the technical terms of artisanal fishing whose concepts are constructed by conceptual metaphors. The purpose of this paper is to consider the phenomenon of conceptual metaphor from the TMC (Theory of Conceptual Metaphor), proposed by Lakoff and Johnson and the science that is concerned with describing the specialized discourses in the areas of activity, Terminology, noting that every profession has its own vocabulary, a glossary that allows more effective communication between those working in a certain area of human knowledge. It consists of a study proposal that relates theory and empiricism. One of the hypotheses is that the language and thought pole interacts in the production of the metaphors present in the vocabulary of fishermen and in the lexicalconceptual structure of language, and establishes relations between the lexical units, from the more general ontological network. The thematic makes use of the method of categorization of prototypical effects, and is based on applications of linguistic surveys with people who work in the fishery of that commune. The corpus consists of oral texts. For this, we use the corpus analysis (corpus analysis), in which the phenomenon of interest is explored; The methodology based on the use and the PIM (Processing of Identification of the Metaphor). Data collection and analysis follow the example of prototype analysis. The main findings reveal that there are two plans: the conceptual plane (which relates concepts) and the

* Universidade Federal da Bahia.svencris@gmail.com 
plane of expression (the words that are used to express these concepts) to demonstrate that the metaphor is not random, but is based on the relation between Concepts in the radial network of concepts. One of the main contributions of this work to the field is expected to be the application of the conceptual metaphor model on the nature of cognitive mechanisms in the technical terms of a language of specialty.

Keywords: conceptual metaphor; cognition; specialized language.

\section{INTRODUÇÃO}

Uma das primeiras declarações sobre a metáfora se destina aos gregos e devese a Aristóteles a parcela dessa contribuição. Parece razoavelmente abrangente que o conceito aristotélico começa a ser questionado em estudos de diversos autores. Lakoff e Johnson (1980/2002), por exemplo, compartilham a ideia de que a metáfora representa um papel importante no pensamento; é um fenômeno de natureza conceptual e de uso cotidiano, por envolver a conceptualização de um domínio de experiência em termos de outro. Assim, nada obstaria, em princípio, que a necessidade de investigações empíricas sobre o processo de compreensão da metáfora possa ser um caminho para desvendar seu status epistemológico. Os estudos da Metáfora Conceptual mostram que os conceitos são interacionais e fundamentalmente cognitivos. A metáfora é, assim, de interpretação complexa, por não se tratar de problemas lógicos e de condições necessárias e suficientes, não devendo esta ser entendida como um fenômeno meramente individual e interno. Pode-se dizer, portanto, que se busca construir uma amostra observável quanto à natureza do objeto de estudo. Assim, a escolha pela temática sobre língua de especialidade da pesca e metáfora conceptual recai sobre a curiosidade investigativa da autora em querer compreender como é possível relacionar o individual e específico de uma língua com o coletivo e o pensamento da ação. Nesse sentido, é possível assegurar que o desenvolvimento da reflexão da metáfora pode ser pesquisado em várias perspectivas, desde a clássica tradição aristotélica até as mais recentes teorias da metáfora, a exemplo da Teoria da Metáfora Conceptual (TMC), a qual ajuda a conferir a este trabalho um viés cognitivista, experiencialista. Portanto, procura-se demonstrar alguns exemplos de metáforas conceptuais decorrentes das experiências cotidianas do universo da pesca da comunidade de Baiacu - Vera Cruz - Bahia, e tecer considerações de como essa língua de especialidade produz, entende experiência e compartilha conceitos de uma mesma maneira, como tal grupo compreende essas experiências e como a cultura faz parte dessa interpretação.

\section{METODOLOGIA}

Como a metáfora se faz presente na língua de especialidade da pesca? As metáforas presentes no ambiente da pesca exploram a natureza da metáfora, a partir do pensamento $x$ linguagem, metáforas conceptuais, no dizer de Lakoff e Johnson (2002), ou a partir da 'palavra' e da sentença? Em razão desses problemas e/ou dessas perguntas é que se estabeleceu a escolha da metodologia, a fim de buscar respostas para sustentar a pesquisa. Sendo assim, a metodologia concilia a pesquisa bibliográfica com dados de cunho empírico, e é definida em função do que se pretende discutir. 


\section{Etapas da pesquisa}

O recurso metodológico utilizado para delinear a linha deste trabalho, assim como contextualizar o campo de estudo que serve de base para a investigação, subdivide-se em: 1) a fonte: constituição do corpus; 2) levantamento dos dados; 3) delimitação do corpus; 4) técnicas de pesquisa: coleta e alinhamento do corpus; 5) o campo de estudo: a comunidade de Baiacu; 6) os participantes, 7) pesquisa de campo, 8) pesquisa bibliográfica.

O corpus deste trabalho constitui-se de dados linguísticos da variedade falada por pescadores da comunidade do Baiacu, Vera Cruz, Bahia. É uma proposta de metodologia empírica, com base nas aplicações de inquéritos linguísticos com pessoas que trabalham na pesca. A seleção e recolha dos dados se deu, inicialmente, a partir de levantamento e análise das ocorrências metafóricas e toma-se como base o PIM. O Procedimento de Identificação de Metáforas sistematiza um conjunto de métodos, e consiste em reconhecer padrões que identificam metáforas linguísticas (PRAGGLEJAZ, 2009; SIQUEIRA et al., 2009). A organização é por categoria contínua. A metodologia consiste ainda em pesquisa bibliográfica e pesquisa de campo.

\section{Procedimentos Metodológicos:}

Os procedimentos metodológicos e técnicas utilizados seguiram e respeitaram os seguintes passos:

a) Etapas metodológicas

A primeira etapa metodológica consistiu na pesquisa bibliográfica e pesquisa de campo. Para a pesquisa bibliográfica, foram realizados estudos teóricos dos principais autores que trataram do assunto. Realizaram-se, também, pesquisas na Internet, em revistas, teses, dissertações e dicionários especializados, a fim de fundamentar a reflexão e argumentação do trabalho. Para a pesquisa de campo, procederam-se à observação constante e sistemática do corpus. A segunda etapa metodológica consistiu em análise das transcrições dos dados.

b) Seleção dos Informantes

O trabalho constou da participação de 35 (trinta e cinco) informantes, sendo que os depoimentos de 21 (vinte e um) deles estão gravados em fita cassette, CDROM, pen-drive e mp5, e transcritos, enquanto que os demais se encontram em caderno de notas, e também disponíveis em bibliotecas, presentes na dissertação da dissertação de Moreira (2010). Desses informantes, constam uma marisqueira e trinta e quatro pescadores. A maioria dos inquiridos é constituída de homens, por ser a pesca uma atividade predominantemente masculina. Ao escolher os informantes, teve-se o cuidado de selecionar os nascidos na comunidade e que jamais tivessem fixado moradia em outro lugar. Cada um dos informantes deixou impressões acerca de suas vidas, sua lida e do papel que desempenha no ambiente do ramo pesqueiro. 
No que tange à transcrição dos inquéritos, alguns critérios foram obedecidos:

1. Sinais adotados nas transcrições:

2. Uma pausa menor é indicada por meio de reticências [...], uma maior, por meio de reticências entre parênteses $[(. .)$.$] ;$

3. Incompreensões, dúvidas e suposições de algumas unidades conceituais foram indicadas pelo ponto de interrogação [?];

4. As explicações do inquiridor figuram entre parênteses duplos [(())];

5. Cortes de trechos de fala são indicados por colchetes [[...]];

6. Os nomes dos informantes são indicados apenas pelas iniciais maiúsculas;

Sobre o contexto das unidades conceituais:

A transcrição é grafemática. Todas as formas foram transcritas da mesma maneira que realizadas pelo falante, compreendendo os termos que são objetos da questão e o contexto em que estão inseridos. As metáforas conceptuais aparecem escritas em letras maiúsculas. $\mathrm{O}$ contexto em que se encontram as unidades/conceitos está registrado em itálico, tal como foi realizado pelo informante, e em negrito.

\section{A comunidade de Baiacu-Vera Cruz, Bahia}

Em termos bem sucintos, dados e informações contidos na história da Ilha de Itaparica remetem, especificamente, à pesca, por exemplo, à questão da introdução a caçadas de baleias em 1603, na Ponta das Baleias, onde hoje é a cidade de Itaparica. Lá foi construída a primeira armação de caça a esses mamíferos.

A Vila de pescadores do Baiacu é uma comunidade pertencente ao município de Vera Cruz, situado na Ilha de Itaparica. Distante de Salvador 43 quilômetros, está localizada na contra costa da Ilha. A localidade do Baiacu é remanescente da primeira ocupação da Ilha, em 1560, sendo a mais antiga e importante colônia de pescadores que tem a Ilha. No início, Baiacu era a mais importante e tradicional das 27 comunidades existentes na Ilha de Itaparica, devido ao fato de ter sido o único vilarejo onde o jesuíta Luís da Grã e seus companheiros de catequese aportaram e edificaram a segunda igreja católica matriz, no Brasil, sob a invocação do Nosso Senhor da Vera Cruz. Baiacu tem como origem o termo Mayacu. Com base em dicionários, o termo [maya'ku] é um termo tupi que caiu em desuso na época pós-clássica, devido a motivos fonéticos. Teria o termo Baiacu surgido por influência do substrato no campo da fonética? Na conjuntura atual, o que se tem percebido na comunidade é que o topônimo Baiacu está em processo de mudança - ou variação entre os termos [Ba'jaku] e [Baja'ku].

O pequeno povoado do Baiacu é composto por marisqueiras e pescadores artesanais que buscam na pesca de peixes e mariscos sua subsistência e única fonte de renda. 


\section{Sobre os participantes}

O trabalho consta da participação de 35 informantes. Desses informantes, constam as presenças de uma marisqueira e 34 pescadores, todos eles com idade compreendida entre 21 a 86 anos. A maioria é constituída de homens. Ao escolher os informantes, teve-se o cuidado de selecionar os nascidos na comunidade e que jamais tivessem fixado moradia em outro lugar.

\section{BASES TEÓRICAS ACERCA DA METÁFORA CONCEPTUAL}

Conceitos advindos desse campo teórico possibilitam apresentar algumas indagações, a exemplo de: o que é e o que inferir sobre a Metáfora Conceptual? Como indaga Teixeira (2013), durante aulas e encontros de orientação, o que a figuração representa? É um problema ontológico? Ou somente um fato pode representar outro fato?

Todos sabem que, nos primórdios dos estudos nessa temática, o significado lógico afigurava o mundo, i. e., precisava ser verdadeiro ou falso. É o estar e o ser da significação. É a contradição da figuração. Mas, sabe-se, há muito, que toda figuração não pode ser lógica no espaço da visibilidade, não pode afigurar toda a realidade, mas a sua própria forma de figuração. É neste ponto que se configura a Metáfora Conceptual? Seria esta constituída de uma relação paradoxal, um sinal complexo entre A e B? Ou uma relação assimétrica para mostrar que a ordem é importante?

O termo metáfora vem do grego 'metapherein', que significa 'transferência' ou 'transporte'. O esquema imagético por detrás desse termo é a transferência do movimento projetado de algo que é ordenado de um presente dêitico para o futuro dêitico, na perspectiva de alguns cognitivistas. Quer dizer, a metáfora é vista como um movimento físico de sentido de uma coisa para outra. Estaria aí algo que se encontra de fundamental sobre a metáfora, que não existe um sentido unívoco de uma palavra: ela terá o seu significado dependendo do jogo da linguagem no qual é usada. As semelhanças entre diferentes jogos de linguagem revelam pontos em comum em nosso modo de viver e de abordar o mundo. Essas semelhanças são denominadas de 'semelhanças de família' e são o que têm em comum os diferentes jogos de linguagem, porém não há um traço compartilhado por todos os membros da família (os mais centrais, com suficiente similaridade ao protótipo), mas um conjunto de traços que permite compartilhamentos parciais (os periféricos, que constituem efeitos de prototipicidade e apresentam poucos traços em comum com o núcleo categorial), sem haver um traço definidor. Não há um denominador comum a todos eles, daí a dificuldade de definição a partir de traços necessários e suficientes. O conceito de semelhança de família, também adotado por Rosch (1975), isto é, a rede de traços desigualmente distribuídos, de modo que nenhum prevalece na definição global do tipo familiar, é de suma importância para a compreensão da categorização por protótipo e da Teoria Metáfora Conceptual. Quer dizer, metáforas não são percebidas mais de forma isolada como um fenômeno exclusivo de língua, mas sim, como uma expressão de estruturas conceituais e de capacidades cognitivas. 
Autores que se debruçam sobre esse fenômeno explicam possíveis desdobramentos que permitem projetar o "apreensível" diante do abstrato.

Dentro dessa perspectiva, conforme salienta Schröeder (2004), é preciso distinguir aqui os termos Teoria Cognitiva da Metáfora, que inclui todas as abordagens pertencentes ao paradigma holístico da Linguística Cognitiva, e Teoria Conceptual da Metáfora, que se refere, exclusivamente, à teoria de Lakoff e Johnson. Isto porque no cenário das primeiras três décadas do século passado surge um crescente interesse pela metáfora como fenômeno cognitivo influenciado pelo clima de vertentes distintas, tais como (1) a do neokantianismo, que culmina no ensaio Philosophie der symbolischen Formen, um dos mais importantes proponentes da teoria cognitiva da metáfora no campo da filosofia, (2) a da crítica da linguagem, representada pelas abordagens de Fritz Mauthner, e, mais tarde, de Ludwig Wittgenstein, (3) a da linguística alemã do século XIX pré-estruturalista, que se caracteriza pelo grande interesse em aspectos diacrônicos, buscando superar o positivismo linguístico através de um idealismo linguístico influenciado por Humboldt e, finalmente, (4) a da Psicologia da Gestalt, particularmente de Christian von Ehrenfels, que exerce um papel importante na Escola de Würzburg. No âmbito dos estudos linguísticos, pode-se observar o desenvolvimento de duas linhas principais que antecipam as suposições básicas da teoria cognitiva da metáfora: o campo de imagem doador e o campo de imagem recebedor, que podem ser facilmente ligados aos termos "domínio-fonte" e "domínio-alvo" de Lakoff e Johnson. Karl Bühler e Wilhelm Stählin se tornam praticamente precursores da teoria da mesclagem metafórica, por fundarem uma teoria interacionista na qual os dois domínios a serem mesclados interagem de modo recíproco e não unidirecional. Deve-se ainda acrescentar que, em 1993, Lakoff aborda sobre a teoria contemporânea da metáfora. Se, em sua origem, o estudo da metáfora pertencia ao campo da Retórica e do discurso poético, e deve-se a Aristóteles a parcela dessa contribuição, nas versões mais contemporâneas, especificamente nas ciências da linguagem e na psicologia cognitiva, a metáfora: "[...] é principalmente um modo de conceber uma coisa em termos de outra, e sua função primordial é a compreensão" (Lakoff e Johnson, 1980/2002, p. 92). Ou ainda,

[...] alternativa experiencialista, dar-se um novo sentido aos velhos mitos, as propriedades que caracterizam o conceito de objeto são interacionais [...] as propriedades não formam simplesmente um conjunto, mas uma gestalt estruturada com dimensões que emergem naturalmente da nossa experiência (Lakoff e Johnson, 1980/2002, p. 213).

Para Lakoff e Johnson (1980/2002), o conceito metafórico estrutura o pensamento e a ação humana. A hipótese que subjaz a esse ponto de vista é a de que a metáfora está presente na linguagem cotidiana, com particular interesse às relações entre a cognição, às capacidades cognitivas e às construções categoriais e conceptuais. Conforme Silva (2012), uma vasta produção de estudos e pesquisas sobre a metáfora teve surgimento, sobretudo nos últimos 30 anos, e um dos trabalhos basilares acerca da metáfora como "imaginação racional" originou-se das ideias de Lakoff e Johnson, com a Teoria da Metáfora Conceptual (TMC), em que a representação mental precede a realização linguística. 
As metáforas conceptuais são, geralmente, corporificadas, isto é, possuem uma base no corpo humano. A mente corpórea é a premissa da embodiment, segundo a qual as experiências por meio das ações do corpo são responsáveis pelo embasamento da linguagem e do pensamento. Quer dizer, é o caráter corpóreo da linguagem, da percepção, do movimento corporal, da experiência física e social. A linguagem, a mente e o mundo como interdependentes. A estrutura conceptual e a linguagem do Domínio-Fonte (DF) são usadas para retratar uma situação no Domínio-Alvo (DA). A pressuposição central é a de que, na base das formas linguísticas, está a função pautada nas experiências e interações do homem com o meio. Sob essa perspectiva, as palavras não contêm significados, mas orientam a construção do sentido. $\mathrm{O}$ realismo experiencialista estabelece que dada à forma e à configuração de nossos corpos e cérebros, estabelece-se necessariamente uma perspectiva particular entre várias perspectivas possíveis e igualmente viáveis em relação ao mundo.

Com a publicação do livro Metaphors we live by, Lakoff e Johnson (1980/2002) passam a desenvolver pesquisas sobre a metáfora do ponto de vista da cognição, tentando demonstrar que não existe uma faculdade autônoma da razão desvinculada das capacidades corporais, tais como a percepção e o movimento e que, portanto, a tese do significado corpóreo, da cognição corporificada, não pode ser tomada como produto do raciocínio consciente, mas como resultante da interação com o meio ambiente com base no corpo e na mente humanos. Essa obra rompe com a tradição retórica e propõe uma mudança paradigmática reformulando a maneira de conceber a objetividade, a compreensão, a verdade, o sentido e a metáfora. A hipótese que subjaz a esse ponto de vista é a de que a metáfora está presente na linguagem cotidiana, em qualquer manifestação discursiva, seja ela literária ou não. As metáforas, além de serem conceptuais, são convencionalizadas, mantêm o princípio de invariância, fazem o mapeamento no esquema genérico. O sistema das metáforas conceptuais convencionais é essencialmente inconsciente e automático. Baseia-se em correspondência entre dois domínios, e não em similaridades. Em termos bem sucintos, a TMC é um instrumento complexo de formação de conceitos. Devido à importância atribuída a tal processo cognitivo, os estudos sobre a metáfora têm propiciado hipóteses de mapeamentos entre domínios conceptuais; tais mapeamentos são assimétricos e parciais; cada mapeamento é um conjunto fixo de correspondências. Vereza (2010) ressalta que, na TMC, a metáfora é considerada objeto de estudo da cognição e mapeamento humanos, de deslocamento ou instância semântica e de motivação ou explicação para expressões metafóricas. Algo digno de nota para essa concepção da metáfora é assumida por Gonzalez-Marquez et al. (2007:

Since Lakoff and Johnson (1980), cognitive linguists have argued that these conventional expressions are not isolated, but are related in slightly different ways to a single underlying conceptual metaphor [...]. This conceptual metaphor is presumed to be part of people's ordinary conceptual system that functions automatically [...] (GONZALEZ-MARQUEZ et al., 2007, pp.05-06). 
Essa natureza da metáfora é explicada por Lakoff e Johnson (1980/2002) como correspondência, mapeamento entre A é B, domínio- alvo e domíniofonte. Tal afirmação vem desde quando a obra Metaphors we live by foi escrita, em 1980, antes da era da ciência do cérebro e da computação neural, e alguns resultados têm resistido ao teste do tempo, a exemplo de: as metáforas são mapeamentos conceptuais, elas fazem parte do sistema conceptual e não são apenas expressões linguísticas. Diferentes expressões linguísticas podem expressar algum aspecto da mesma metáfora; a metáfora conceptual pode ser utilizada na compreensão de uma palavra, mesmo que a palavra não esteja realizada no domínio-fonte da metáfora.

A questão de que se trata aqui é a de que a TMC parte da premissa de que a base experiencial é formadora do sistema conceptual humano. Isto equivale a dizer, conforme assinala Vereza (2010), não ser estranho que a metáfora conceptual esteja estritamente ligada a um conjunto de valores de uma determinada comunidade; que a metáfora é um produto da cultura, da ideologia e da história características da experiência em um determinado grupo social. Na TMC de Lakoff e Johnson (1980/2002), falar metaforicamente é uma decorrência natural do fato de que as pessoas pensam metaforicamente. Para eles, essas maneiras metafóricas de falar se incorporam à vida cotidiana de tal modo que as pessoas passam a viver regidas por elas, porque são verdadeiros sistemas metafóricos e que através deles se pode compreender a maneira pela qual o individuo concebe a realidade. A metáfora, um dos modelos cognitivos idealizados e proposto por Lakoff e Johnson, pode ser, então, considerada como uma transfiguração ou uma reconfiguração de uma coisa em outra sem que necessariamente a outra coisa seja substituída ou chegue a se desfazer.

As metáforas não são apriorísticas. Antes, elas dependem da experiência. Os dois domínios, que são distintos, se acham simultaneamente presentes; em momentos um é mais iluminado e o outro se obscurece e vice-versa. Ora são mais emergentes, de fácil identificação; ora são mais implícitos, não há relação direta; ora se apresentam de maneira mais imediata à percepção, ora é preciso compreendê-los a partir de uma maior abstração. Mas não formam uma imagem única. São estruturados normalmente a partir de um conceito mais concreto para um mais abstrato. Há uma sobreposição, no sentido de não saber quando termina um domínio e começa outro.

As metáforas conceptuais são motivadas e baseadas na experiência corporal, como o corpo humano funciona e interage com o mundo físico, tal como também e tratado nos estudos de Batoréo (1997). O funcionamento da metáfora encontra-se no enunciado metafórico quando de sua interpretação depender o processo cognitivo de projeção, isto é, certas propriedades atribuídas a um evento são projetadas em outro evento. Quanto a isso, é possível considerar o que Zanotto chama de 'papel heurístico' da metáfora, por ser esta um processo de mudanças conceptuais.

Como resultado, nos últimos tempos, a metáfora passa a ser interpretada como sistema próprio de pensamento e de categorização e ação humanas. Contrasta com a ideia de alguns dos termos que outrora eram utilizados para caracterizá-la, como: comparação, analogia, similaridade, entre outros. Tais termos são diferentes dos utilizados pelos cognitivistas que recorrem ao uso de predicadores, tais como: 
metáfora conceptual, correspondência, interação, mapeamento, paralelismo, representação, reflexo, referência, projeção, inferência, e também conceitos que representam significações, tais como: metáforas novas, metáforas velhas, metáfora de uso, metáfora como processo, metáfora cristalizada, metáfora in praesentia, metáfora in absentia, metáfora conceptual. De acordo com Zanotto (2007), esse comportamento reafirma o redirecionamento para o estudo acerca da metáfora, preocupando-se em demonstrar a interrelação entre linguagem, cognição e mundo com base na experiência corpórea. Essa é a ideia que permite Zanotto realizar, em 2007, uma investigação empírica com o objetivo de mapear os tipos de indeterminação da metáfora em uso, descrevendo sua especificidade. Para ela, pode haver metáfora polissêmica, ou ambígua, ou vaga:

[...] a metáfora não é um tipo a mais de indeterminação ao lado da polissemia, da vagueza e da ambiguidade, mas apresenta esses tipos assim como a linguagem literal [...] no caso da metáfora, essa indeterminação não se especifica ou não se resolve no contexto, nem com o conhecimento da intenção do autor [...] exatamente isso que torna a metáfora algo especial [...] Por isso acredito que pesquisar empiricamente como leitores reais interpretam a metáfora poderá contribuir para a elucidação desse fenômeno complexo que é o seu sentido indeterminado (ZANOTTO, 2007, pp. 98; 101).

Essa 'indeterminação’ representa os múltiplos sentidos, é inerente à natureza metafórica. Para entender esse princípio, Vilela (1996), tendo por base as postulações de vários teóricos, afirma que os cognitivistas revalorizaram o papel da metáfora, quer em si mesma, quer em relação à metonímia e sinédoque, quer como criações novas, quer como enriquecimento dos processos de configuração da realidade circundante: a existente e a emergente. De acordo com ele:

[...] a semântica dos 'frames', de Fillmore, as noções de 'script', de Roger Schank, de 'linguistic gestalts', e 'experiential gestalts', de George Lakoff e Mark Johnson, da 'semelhança de famílias', de Ludwing Wittgenstein, do 'protótipo' e 'estereótipo' de Eleanor Rosch e Putnam [...] deram à metáfora um papel ainda mais relevante do que aquele que até então lhe tinha sido dado (VILELA, 1996, p. 325).

A TMC permite entender mais sobre esses elementos conceptuais. Explica como os conhecimentos que um indivíduo possui estão estruturados na mente e como eles são acionados para resolver problemas. Lakoff e Johnson (1980/2002) consideram-na enquanto relação entre razão e imaginação. A primeira envolve a categorização, a implicação e a inferência. A segunda implica ver um tipo de estrutura em termos de outro. Como se pensar que uma estrutura mais concreta e bem definida do domínio-fonte fosse projetada para o domínio-alvo, estruturando (cf. FERRARI, 2016). Daí se pensar a metáfora como racionalidade imaginativa: “[...] as metáforas como expressões linguísticas são possíveis precisamente por existirem metáforas no sistema conceptual de cada um de nós [...] metáfora significa conceito metafórico” (Lakoff e Johnson, 1980/2002, p.48). Esses pesquisadores creem na existência de uma preservação da tipologia cognitiva do domínio-fonte de forma coerente com a estrutura inerente do domínio-alvo, devido aos mapeamentos metafóricos que colaboram na sobreposição de imagens 
mentais do indivíduo, decorrente da semelhança entre as duas entidades. Ao que se segue, a experiência é base formadora do sistema conceptual humano e a natureza da metáfora é fundamentalmente conceptual. A estrutura corresponde a mapeamentos entre domínios conceptuais não arbitrários, mas com base no corpo e na experiência e conhecimento cotidianos.

3.1. Terminologia: a importância das metáforas no vocabulário de especialidade

A metáfora, na ciência, é uma parte central da maneira como as teorias sobre o mundo são expressas. A ciência, assim como a arte e a religião, é um produto de fluidez cognitiva. Sabendo-se que o uso da metáfora permeia a ciência (exemplos bem conhecidos "o coração é uma bomba mecânica"; "os átomos são sistemas solares em miniatura"; "DNA egoísta") contribui para compreender o motivo pelo qual o fenômeno das metáforas tem sido amplamente discutido por filósofos, que reconhecem seu papel crítico não apenas na transmissão de ideias, mas na própria prática científica. A metáfora se projeta nos aspectos do pensamento e forma o cerne da expressão da arte, da religião e da ciência. Para especificar os atributos da mente tem-se que mencionar o uso de metáforas. Para entender as ideias, os cientistas estão predispostos não apenas a valer-se de metáforas, mas também a escolher aquelas que recorrem ao mundo social dos humanos.

Quando se debruça em torno do percurso da ciência terminológica dos primórdios à atualidade, já se percebe o uso de metáforas no vocabulário de especialidade, já que a utilização de termos dentro de áreas técnico-científicas é uma prática que remonta desde a Antiguidade. Crátilo, de Platão, é o primeiro texto básico de Terminologia. Mateus e Correia (1998) registram que "[...] as primeiras tentativas de ordenação sistemática de vocabulários específicos remontam ao início da Idade Média, início do século XVI [...], e situam-se nas áreas das ciências exatas" (Mateus e Correia, 1998, p. 13). Assinalam, ainda, as autoras que o estudo em torno da especificidade da linguagem encontrase associado ao léxico e à própria Terminologia: “[...] de modo diverso, uma terminologia é caracterizada pelo facto de os elementos que a constituem serem unívocos, ou seja, a cada termo corresponder apenas um significado no universo de referência" (Mateus; Correia, 1998, p. 09). E para ratificar essa ideia, citam Castellví:

Si la ordenación del pensamiento y la conceptualización representa la dimensión cognitiva de la terminología, la transferencia del conocimiento constituye su dimensión comunicativa: la terminología es la base de la comunicación entre profesionales (MATEUS; CORREIA, 1998, p.23).

Não era bem vista a ideia de um texto especializado conter termos ou definições terminológicas polissêmicas. Os elementos fundamentais na linguagem técnico-científica eram objetividade, clareza e precisão. Uma crença objetivista (Siqueira et al., 2007). 
De acordo com Alves (1996; 2010), a Terminologia é um conjunto organizado de unidades léxicas de uma língua que são utilizadas em uma mesma sincronia. A autora, ao citar Francis Aubert, assegura que as linguagens de especialidade fazem parte de termos que não existem em isolamento, nem derivam sua existência apenas de um arcabouço lógico-conceptual, mas se manifestam, circulam e exercem sua função em situação, em uso efetivo. Afinal, como assegura Alves (2010), uma ciência se faz com terminologia.

Outrora, a Terminologia se preocupava com a visão estática e normalizadora dos termos, cujo objetivo era sistematizar os discursos especializados nas áreas do saber ou de atividade. No sentido mais estrito, a representação que se tinha para a Terminologia era a de ciência da sistematização de termos e conceitos. De acordo com Siqueira et al. (2007), o princípio da teoria tradicional da Terminologia da Escola de Viena considera a comunicação sem ambiguidades como o ideal para a linguagem científica, sendo preferível substituir um termo metafórico pelo seu equivalente literal. Para essa teoria, a metáfora é apenas relevante enquanto recurso da capacidade linguística de nomear as coisas:

Terminólogos mais tradicionais [...] acreditam que um conceito surge independentemente da
linguagem, pois ele deve existir de maneira clara e objetiva, fazendo parte do mundo real. [...]
A teoria tradicional da Terminologia é coerente com um modelo objetivista da realidade. No
fundamento da teoria está a crença de que há um mundo objetivo a ser estudado de forma
também objetiva. A Terminologia tradicional acredita que a linguagem deve ser controlada
(padronizada) para que se assegurem a objetividade, a eficiência e uma compreensão bem
definida. Fora essa razão, afirma-se que lexicalizações literais são preferíveis a metaforizações.
(SIQUEIRA et al., 2007, pp. 220; 231).

$\mathrm{Na}$ atualidade, a evidência do trabalho terminológico consiste em representar o campo conceptual e não apenas estabelecer as denominações precisas que garantirão uma comunicação profissional rigorosa. Hoje, entendese o funcionamento da Terminologia em um contexto mais amplo, no espaço da interação social, com o objetivo de descrever e analisar as variantes terminológicas, levando-se em consideração os avanços da Ciência linguística e da Socioterminologia, em detrimento dos propósitos normalizadores. Conforme Faultstich, a Terminologia é uma disciplina que deve explicitar o semanticismo do termo como signo linguístico, como fenômenos variáveis que ocorrem no sistema interno da língua, na qual estão redigidos os textos de especialidade. E como tal, devem-se criar critérios de sistematização que dividam as variantes em dois grandes grupos: variantes linguísticas e variantes de registro. A autora classifica as variantes linguísticas, obedecendo aos seguintes princípios: o da interpretação semântica, base para análise do termo; o das unidades terminológicas complexas, analisadas sob o ponto de vista funcional; o dos subsistemas da língua portuguesa constituídos por fundo linguístico de análise e o dos usos escrito e oral, em que são considerados os termos. A partir daí, é possível estabelecer um relacionamento entre as variantes linguísticas e as variantes de registro (Faultstich, 2002).

Outro pressuposto em torno da Terminologia é o apresentado por Krieger (2004), que observa os dois pontos de vista distintos dessa ciência. De um lado, encontra-se uma visão estática e normalizadora dos termos, expressão da dimensão conceitual sob a qual a Escola de Viena define seus princípios e métodos; de outro, a 
ótica linguística que entende o funcionamento das terminologias no contexto de sua naturalidade aos sistemas linguísticos e às formas pragmáticas de sua materialização nos textos especializados, em que a Terminologia adquire uma identidade própria e independente em relação à Lexicologia e à Lexicografia. Krieger (2004) assinala que na origem das reflexões sobre o nome e a denominação, base da Terminologia, encontra-se toda a reflexão sobre a linguagem e o sentido. Para ela, a relação entre a Semântica de cunho linguístico e a Terminologia é marcada por algumas peculiaridades, uma das quais se refere ao estatuto das unidades lexicais, quando elas assumem vínculo à sua face conceitual e às relações estabelecidas entre conceitos que se inserem no interior de uma área de conhecimento, dada sua orientação fundamentalmente onomasiológica. Krieger (2004) verifica que a Terminologia assume um caráter metodológico, de natureza prescritiva e normalizadora, em detrimento da apreensão quanto aos modos de funcionamento dos léxicos terminológicos.

Outrora, o estudo da Terminologia era somente no campo conceitual, mas atualmente se alarga para outras áreas, havendo um redimensionamento, pois a moderna concepção informa que os termos são unidades lexicais, podendo ser metafóricas e metonímicas.

Essa concepção passa a ser analisada, de acordo com Krieger (2004), a partir da década de 90, época em que se intensificam os estudos fundamentados na complexidade que envolve o funcionamento dos termos, tal como qualquer unidade da língua natural. Contribuem para esse redimensionamento importantes investigações de linguistas, destacando-se a preocupação sociolinguística, bem como de pesquisadores de formação filosófica e tradutológica, além de contribuições provenientes da inteligência artificial que motivam a Terminologia a avançar na perspectiva de estudos descritivos. Do mesmo modo, garante a autora que, no caso das denominações técnicas, o componente lexical especializado permite ao homem denominar objetos, processos e conceitos que as áreas científicas, técnicas, tecnológicas e jurídicas criam e delimitam conceitualmente. Por isso, os termos realizam duas funções essenciais: a de representação e a de transmissão de conhecimento especializado. Do ponto de vista dessa autora, alguns temas são principais da Teoria Geral da Terminologia, tais como: a essência, as características e as relações dos conceitos dentro dos elementos conceituais; a descrição dos conceitos (mediante definições); a atribuição de termos e conceitos, e/ou de conceitos e termos, a essência de termos e a sua formação. Krieger concorda que os conceitos são elementos da estrutura do conhecimento e, como tal, ocupam um lugar importante dentro da filosofia das ciências e das teorias cognitivas.

Para Velasco (2004), a Terminologia, enquanto campo de estudo, observa os discursos das áreas de especialidade, propondo metodologias para a descrição de seus termos, com a finalidade de estruturar o campo nocional da especialidade. De igual acordo, é possível a Terminologia subsidia ao pesquisador desenvolver reflexões teóricas sobre suas bases conceituais, como metodologias de trabalho. Seus objetivos são aplicados na observação dos discursos especializados nas áreas do saber ou de atividade, visando principalmente à construção de dicionários e glossários especializados. Comenta Velasco (2004) que, funcionalmente, a 
Terminologia é veículo de conhecimento, aspecto importante para a descrição e recuperação da informação, além de explicar o termo, a palavra especializada, os conceitos inerentes às diversas matérias especializadas.

Embora se tenha conhecimento de que a Terminologia, que se ocupa das linguagens de especialidade, surgiu como uma disciplina prescritiva, opondo-se aos estudos científicos da linguagem, aos poucos, essa ciência tem se colocado em uma relação de complementaridade com a Linguística. Ao que se percebe, essa tendência de comportamento já se faz presente em alguns estudos terminológicos. Dentro dessa linha da Terminologia da linguística moderna, tenta-se interpretar e/ou descrever os termos, na medida do possível, em paralelo com a descrição semântica, embora, até bem recentemente, quase não se encontrava alternativa que encobrisse essa temática. Do ponto de vista de Siqueira et al. (2007, p. 184), a Teoria Sociocognitiva da Terminologia é um exemplo dessa conduta, pois "[...] propõe que [...] tanto a univocidade quanto a polissemia e a sinonímia podem ser funcionais e que as expressões figuradas são parte da descrição terminológica" (SIQUEIRA et al., 2007, p. 184).

Para Siqueira et al. (2007):

Entre as pesquisas mais recentes em Terminologia [...] já é consenso a ideia de que esse é um campo de estudo que deve ampliar seu escopo, de modo a englobar a diversidade linguística em todos os seus aspectos, inclusive o figurado. Todavia, ainda são raras as pesquisas enfocando o tópico 'metáfora' em Terminologia (SIQUEIRA et al., 2007, p.182).

Este tipo de interpretação é também reconhecido em trabalhos de Finatto (2007):

Terminologia [...] é uma área de estudos relativamente nova no Brasil, que se dedica ao reconhecimento dos fenômenos que integram a comunicação técnico-científica de acordo com uma perspectiva linguística, social, cognitiva e comunicativa [...] as terminologias revelam, sim, associações metafóricas, quer em suas denominações, quer em suas definições ou explicitações [...] o estudo da metáfora em Terminologia revela o fato de que as terminologias, tomadas isoladamente, apenas nos mostram um pouco sobre a feição das linguagens especializadas [...] já é chegada a hora de investir na ideia da apreciação descritiva e crítica de todo um meio ambiente linguístico e cognitivo da comunicação técnico-científica. A complexidade do tema, o enorme desafio de reconhecer, criteriosamente, o que é ou que não é metafórico e em suas variações só o torna mais instigante e necessário (FINATTO, 2007, pp. 120; 127).

Corroborando o que assinala Finatto (2007) acerca dos estudos de Temmerman, Siqueira et al. (2007) afirmam que Temmerman defende a necessidade de uma nova abordagem na Terminologia e dizem que a pesquisa das metáforas na linguagem especializada possui relevância para essa disciplina. Um de seus postulados é o de que a metáfora é um fenômeno de importância fundamental para os processos de lexicalização:

A Teoria Sociocognitiva da Terminologia (TSC) defende que parte do conhecimento científico e tecnológico é apreendido através de nossas percepções sensoriais, como resultado de interação entre a linguagem, a mente, e o corpo humano e o mundo [...] (SIQUEIRA et al., 2007, p.184). 
Tanto Finatto como Siqueira et al. declaram que Temmerman (2009) investiga o possível impacto da teoria do modelo cognitivo metafórico na teoria terminológica, a partir de categorizações tais como: metáfora do lexema, metáfora da categoria e metáfora da área (Siqueira et al., 2007). Com efeito, nos últimos anos tem-se assistido à integração progressiva dos avanços da Linguística em geral e, em particular, nos estudos em Terminologia, fato que contribui para explicar os processos envolvidos na constituição e uso das terminologias nos diferentes domínios da especialidade.

\section{DESCRIÇÃO DA PESQUISA E DISCUSSÃO DOS RESULTADOS}

Por questão didática, assim como para refinar o objeto de estudo, restringe-se a análise dos dados a um dos conceitos de "pescador", a saber, proeiro/mestre, um dos termos mais salientes utilizados pelos pescadores daquela comunidade para conceptualizar o homem da pesca. Cabe assinalar que, para este artigo, apenas servirá como base de análise uma das dezesseis categorias que foram construídas a partir do corpus, a categoria das metáforas conceptuais de pescador, metáforas provenientes da avaliação (valor) funcional de pescador.

No entanto, para ilustrar os resultados da pesquisa empírica, outros exemplos serão lançados, a fim de que a investigação não fique restrita a um único exemplo.

A seguir, a descrição e a discussão dos dados:

\section{Metáforas conceptuais de Pescador}

$>$ Metáforas provenientes da avaliação (valor) funcional de pescador:

Termo: Proeiro

Significado mais básico: 'Marinheiro dos que vigiam à proa'. Palavra original proeiro (MORAES SILVA, 1813).

Significado no contexto: 'Mestre e ou principal responsável pela organização e atividade da pesca'; 'pescador localizado e com função na proa'.

\begin{tabular}{|c|}
\hline EXPRESSÕES METAFÓRICAS E METONÍMICAS \\
\hline $\begin{array}{l}1 \text { - [...] O proeru é em primero lugá que é o cabesa de (? ). Ele fica na proa, ele que } \\
\text { cerca os lãsu, ele que, se fô vê xãgó, ele que vê o xãgó, aí, ele que vai na proa, é, é dano } \\
\text { instrusãw ao popero [...] (INF. 08, A.G.N., } 25 \text { anos). } \\
2 \text { - [...] O mestri é a profissãw, lansa a redi no má, não só ele como qualqué pessoa pode } \\
\text { lãsá, mas compete ao mestri. (INF.06, J.S.P., } 86 \text { anos). } \\
3 \text { - É o proeru é o mestri da redi. Ele é responsável por tudo porque se, digamos, de } \\
\text { madrugada quem chama, quem vai chamá é ele [...] quem é o cabesa é ele, pra chegá } \\
\text { ali. (INF. 02, C.P.N., } 66 \text { anos). }\end{array}$ \\
\hline
\end{tabular}

Quadro 1: PROEIRO $\leftrightarrow$ MESTRE É CABEÇA 
PROEIRO $\leftrightarrow$ MESTRE É CABEÇA é uma das metonímias conceptuais para Pescador, e tem a prototipicidade bem definida no termo proeiro.

Em alguns dicionários gerais e etimológicos, não se encontram registros do termo proeiro, com exceção de Moraes Silva (1813). Essa metonímia permite compreender a ideia daquele que instrui, ensina, e é responsável por transmitir os conhecimentos da labora da pesca, atributos característicos de mestre, e implica proeiro ser mestre; mestre ser proeiro; proeiro ser cabeça; proeiro estar em primeiro lugar. Esse sentido pode servir de base para a seguinte afirmação de Ribeiro (1984) “[...] sem um mestre a guiá-los, os três moços queriam apenas uma desculpa para a perda da rede que não souberam manejar direito" (RIBEIRO, 1984, p.257). Mestre é o típico conhecedor da cultura da pesca, um guia responsável, pescador mais respeitado entre os demais pescadores e de maior experiência na arte de pescar. Conforme salienta Pelosi (2012), PROEIRO $\leftrightarrow$ MESTRE É CABEÇA não é necessariamente e/ ou que se acredite que seja, pura e simplesmente, uma predicação do tipo "a é b". O conceito não é tão emergente e, sim, mais implícito. Para Teixeira (2014), em PROEIRO $\leftrightarrow$ MESTRE É CABEÇA existe também uma inferência ao nome de uma coisa, isto é, a parte primeira, mais saliente da embarcação, a proa, é cooptada àquele que desempenha a função principal na pesca, que é o proeiro/mestre. Assim, a imagem que se tem é de uma projeção metonímica. Não implica que $A$ é $B$, mas que $A$ contém uma característica de $B$, um modelo $A$ que é transferido para um modelo $B$. $A$ pertence ao modelo cognitivo de $B$. Quer dizer, é um processo metonímico, entidade do mesmo domínio cognitivo. Em termos metonímicos, proeiro é referência direta à proa, parte da frente da embarcação, e serve para o pescador sentar-se ou ficar de pé. Pode-se presumir que mestre e proeiro são dois domínios cognitivos diferentes, confirmando a máxima de que a metáfora $x$ pode pertencer a $y$; quer dizer, os elementos não são exclusivos, mas se fundam numa relação de inclusão, de modo que se pode dizer que um pertence a outro. Assim, proeiro pode compartilhar das propriedades de mestre e servir de suporte à sua representação metafórica. São termos equivalentes. Pode-se falar de mestre em termos de proeiro; e de proeiro em termos de mestre. A base cultural deste conceito está relacionada com a posição de mestre, que pode ser também sistematizada na seguinte estrutura: instrução, profissão, competência, responsável. Nesse caso, além de se poder representar proeiro por mestre, é possível fazer referência a um em vez do outro; mestre por profissão; por responsável; por proeiro. Passa-se a perceber a metonímia tanto referencial como predicativa: Mestre é a profissão; ele é responsável por tudo ( v. exs. $1 ; 2 ; 3$ ). Isto é, mestre é uma realidade comparável à profissão, grupo social, função cultural (ser membro ou fazer parte de um grupo específico, ser chefe de), espacial (dentro-fora) e controle (sai-entra), confirmando o que Lakoff e Johnson (1980/2002) assinalam, isto é, o DA é DF ou DA como DF. 
Em um documentário intitulado "Pesca de mestre", produzido pela Dra. Meirelles, ganhador do Prêmio Arruanda como melhor documentário do ano 2008, exibido pela TV UFBA, é possível perceber que o termo mestre de rede, ou simplesmente mestre, ganha uma extensão simbólica, pela forma de comportamento e de como ele [o mestre] agencia a coesão da equipe. Além disso, outros domínios servem para metaforizar a avaliação e o valor atribuídos à função do pescador mestre, desde o corpo humano ( $a$ abeça), primazia, até a escala positiva em que se encontra mestre ([...] O proeru é em primero lugá que é o cabesa [...], INF. 08, A.G.N., 25 anos). Tem-se aqui a metáfora e a metonímia. Por exemplo, cabeça, parte superior não de um corpo, mas de um conjunto (extensão metonímica); tal como a cabeça é a parte mais importante do corpo, o chefe é o elemento mais importante do grupo (projeção metafórica). São experiências estreitamente correlacionadas. Deve-se falar de cabeça em termos de mestre e de proeiro. No contexto em apreço, cabeça implica a metáfora PARA CIMA para traduzir 'competência', 'entendimento', 'sabedoria', 'responsabilidade'. Quer dizer, cabeça implica relações metonímicas baseadas na corporeidade, na força não física, no todo pela parte, no fundo pela figura, na profissão pelo sujeito. Pode-se ter a metáfora CABEÇA É PONTO DE REFERÊNCIA, tal qual assinalam Farias e Lima (2010), em que esta é uma metáfora orientacional, pois, basicamente contém a noção espacial de cima/ baixo, e determina ordem/desordem. As autoras apresentam também os seguintes significados de cabeça: 'líder', 'ponto vital', 'posição', 'unidade' (grupo), 'ponto de referência'. Assinalam ainda que os conceitos metafóricos correspondem com os significantes culturais. Em proeiro mestre por cabeça, cabeça é a experiência de engagement, de encontro; quer dizer, o corpo em vitalidade e em atividade. A experiência de corporeidade implica as metáforas CORPO É INSTRUMENTO e CORPO É OBJETO. Em cabeça joga-se, essencialmente, com a função referencial metonímica. Conforme explica Vilela (1996), quando se designa alguém por "cabeça" não se introduz apenas uma nova designação ou referência, mas também se salienta a propriedade para a qual se aponta. Quer dizer, a cabeça como sede de inteligência, havendo, dessa forma, um reforço da compreensão, e, evidentemente, do cognitivo. A extensão semântica é polissêmica, através da qual se explica proeiro mestre, por cabeça. As expressões metafóricas e metonímicas que representam mestre são: 


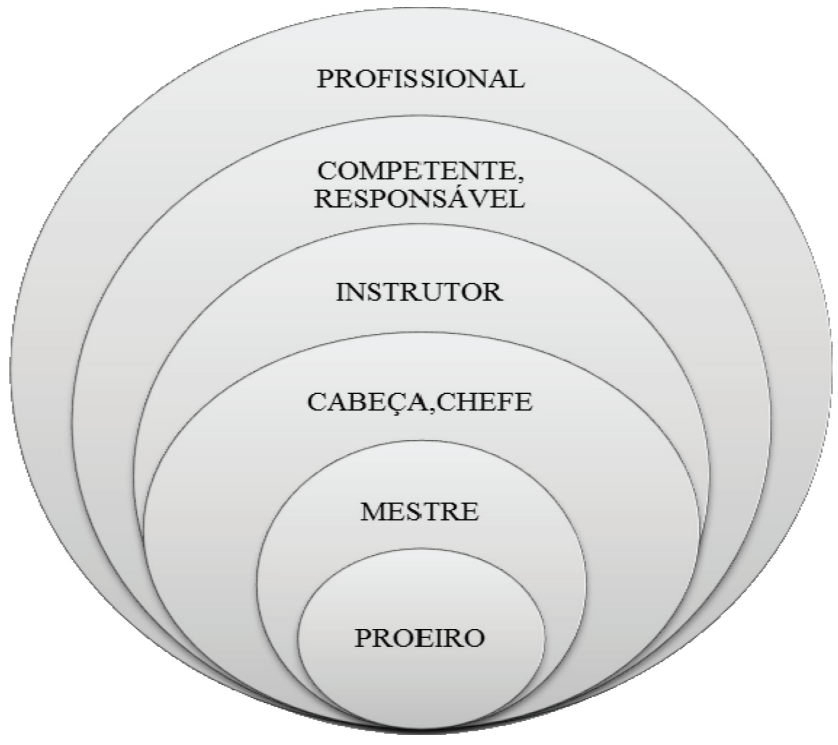

Esquema 1 - Rede radial de PROEIRO

Proeiro mestre, cabeça são mais frequentes. Cada um dos elementos da estrutura de base constitui um tipo de mini- rede de significação.

Nesse caso, proeiro vai designar: 'aquele que é mestre dos outros', 'aquele que pode transmitir conhecimentos a outros'. Há uma hierarquia em que se estabelece o primeiro de todos, com quem se deve aprender e com quem se inicia a pesca, como comprova a expressão descrita no exemplo 1 " "...] O proeru é em primero lugá que éo cabesa de ( ? )[...]". Os modelos cognitivos imagéticos correspondem aos domínios do poder e o do saber. Dois domínios paralelos. Logo, uma rede existente pode dividir-se em duas categorias, ou duas redes podem fundir-se em uma única. No tipo ontológico, a entidade do DA é proa, que se relaciona com a entidade do DF cabeça. Segundo Grady (1997), poderia se ter, nesse caso, uma metáfora de imagem. A proa serve de domínio-fonte a ser pinçado para o domínioalvo (one-shot metaphor). A metáfora de imagem, i.e., de semelhança, não projeta vários conceitos de um domínio-fonte em vários alvos, pois é um tipo de metáfora de uma só projeção.

No tipo epistêmico, a correspondência entre o conhecimento do DA e DF ocorre entre o domínio do saber e o do espacial, demarcando poder, o que possibilita um acarretamento metonímico. O mapeamento é com saber: 'emissor de informações' e com a parte superior do corpo humano com relação ao principal componente da embarcação. Essa relação configura-se no valor positivo atribuído ao mestre, pois ele serve de modelo cognitivo, sendo totalmente responsável pela base imagética dos conceitos culturais, morais e sociais. Para Teixeira (2014), significa dizer que a negatividade ou positividade da fonte e todos os valores a ela associados são elementos importantes para a construção global da associação metafórica. 
Percebe-se que todo o vocabulário usado para falar sobre proeiro origina-se de mestre. Quer dizer, dois domínios pertencentes ao mesmo domínio cognitivo comum, pescador, em que o DF afeta mentalmente o DA.

Como explicação diacrônica:

[...] magister (mâitre- mestre, dono); magisterium ( magistère-magistério) deriva de 'Maistrie', do latim 'magis', que significa 'mais'. Do domínio de origem, que é o da quantidade ( aquele que possui mais), passou-se ao do poder ( aquele que é mestre dos outros). Domínio do poder, houver depois um deslocamento para o domínio do saber (aquele que pode instruir os outros). Finalmente, este deu lugar a uma especialização: 'maîtrise' (mestrado), que indica o grau académico de mestre (Magister Artium) (DELBECQUE, 2006, pp. 286-287).

Partindo do que apresenta Delbecque, traçadamente pode-se apresentar o seguinte esquema em que demonstra a passagem do vocábulo magister de uma rede a outra:

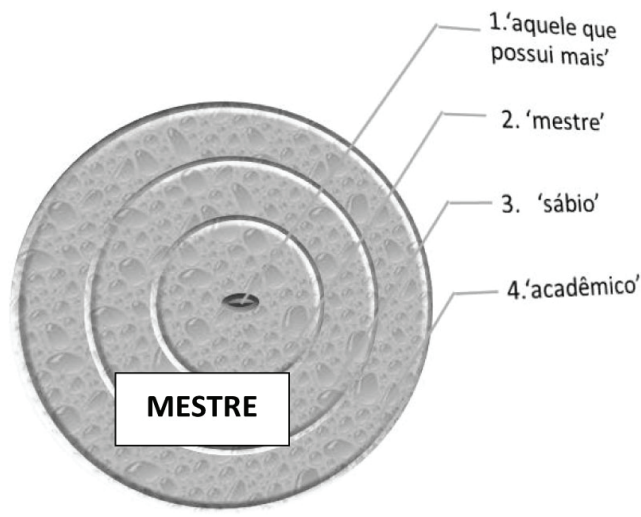

Esquema 2: Categoria radial de mestre, segundo Delbecque (2006).

É interessante notar a inversão na ordem dos sentidos atribuídos a mestre. Em latim, do domínio de origem QUANTIDADE passou para o do PODER, e depois para o do SABER. É o caso de se considerar uma mudança no interior de uma categoria radial. O sentido 'mais' era central, tornou-se marginal e o sentido 'instrução' tornou-se central. A categoria radial corresponde aos diversos usos para o sentido metafórico e metonímico de mestre. Na pesca, especificamente, os conceitos proeiro e cabeça é que acabam por vir a qualificar o saber em geral, porque considerar mestre usando as expressões cabeça, proeiro está a se utilizar uma dimensão metafórica, cujo modelo conceptual pertence à esfera do 'saber', 'transmitir conhecimento a'. Quer dizer, de uma esfera mais abstrata à concreta, considerando que a noção de abstração é relativa. Por outro lado, há de assinalar que cabeça já é considerada uma metáfora lexicalizada, que dizer, não há mais um significado atribuído. Há autores que consideram este tipo de metáfora como "morta" ou "cristalizada", diferentemente da metáfora conceptual, que é traduzida como compreensão de um domínio conceitual em termos de outro domínio conceitual e que tem participação ativa na nossa forma de pensar, agir, e experienciar a realidade. 
Outro exemplo pode servir também de ilustração:

\section{Metáforas conceptuais de Maré}

\section{MARÉ É CONTAINER}

Termo: Maré

Significado básico: 'Movimento de elevação e de abaixamento das águas do mar' (HOUAISS, 2004).

Significado no contexto: 'Receptáculo destinado a acondicionar ou transportar algo'.

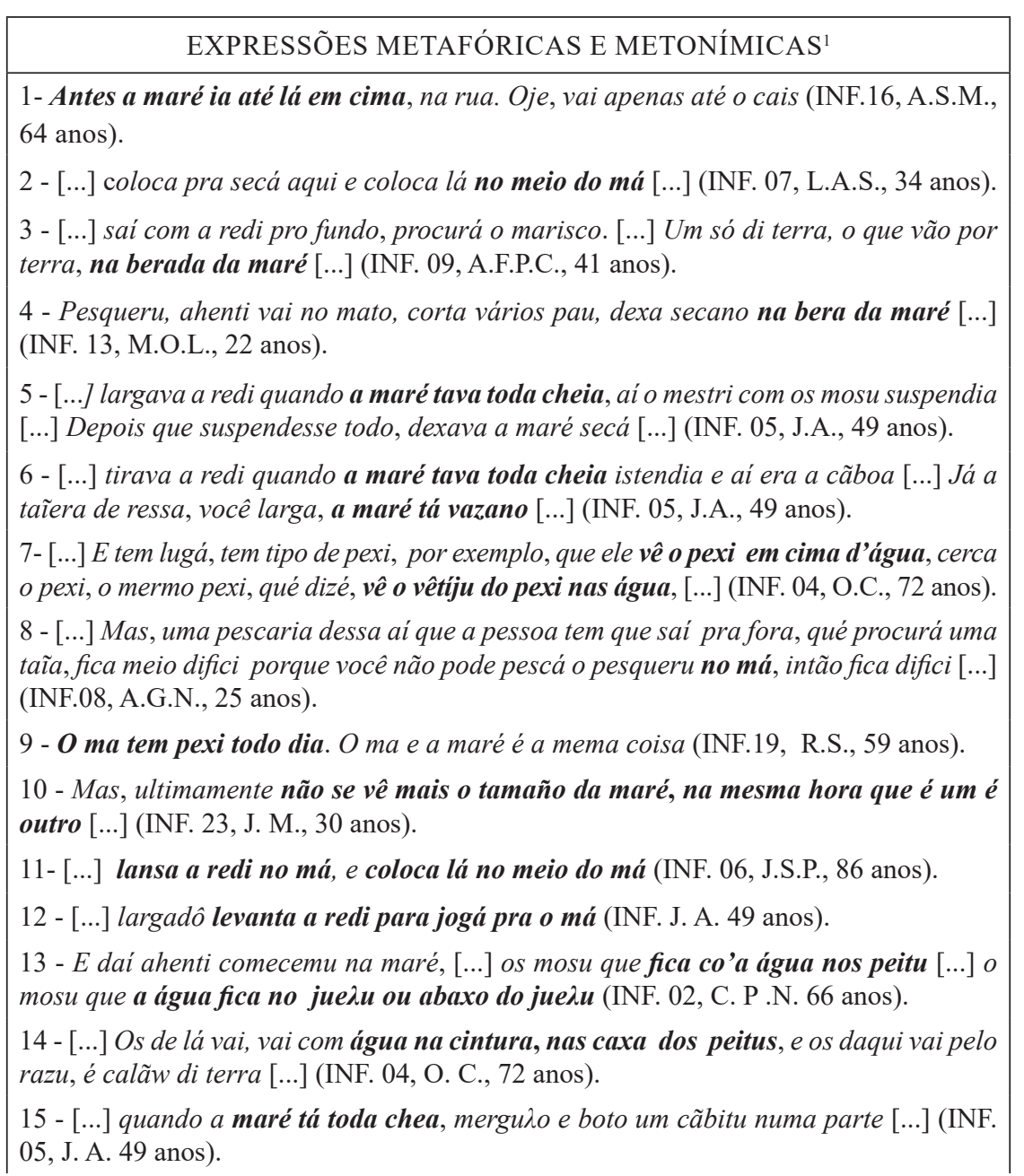

\footnotetext{
${ }^{1}$ Há muitas expressões metonímicas nos termos técnicos da pesca que dão origem a metáforas.
} 
16 - [...] se eu não tivé uma cuia não pode disgotá a canoa, não pode tirá a água de dent'da canoa [...] (INF. 01, M. D. 68 anos).

17 - [...] de longe você vê, po tá lá no arto mar [...] (INF. 03, .J. A. G. 59 anos).

18 - A pesca travessa infíca trêis vara do lado da insiada e mais trêis vara quando a maré tivé alta [...] (INF. 03, J. A. G. 59 anos).

19 - O que tem na maré é só xãgó, massãâê, pescada (INF. 04, O.C., 72 anos).

20 - Já vi bem no meio do má, alguém gritá naquele silêncio todo do má [...] (INF. 03, J. A. G. 59 anos).

21 - Pescadô só não leva pexi pra casa se fô pra o má e não consegui pescá nada (INF. 02, C. P. N. 66 anos).

22 - De dentro do barco largamo a redi e deixamo ela mesma trabaiá, ficá flutuano na água ((INF. 03, J. A. G. 59 anos).

23 - [...] mas a pesca é continuada, se pesca com a maré chea, baxa, [...] (INF. 24, J.X., 43 anos).

24 - [...] o bom da pesca é vé o má, o briגo do pexi, em silêncio [...] (INF. 24, J.X., 43 anos).

25 - Falta pexi no má. (INF. 05, J.A., 49 anos).

26 - [...] antes, não usava nada no má, pra não dá azá e espantá o pexi, que fica na ponta da coroa ou no fundo da maré. Mas, oje, usa sapato, por isso não tem pexi (INF. 05, J.A., 49 anos).

27- A ora da pesca, depende da maré alta, baixa, seca, enchente, que puxa pra terra, vazante, que vai pra fora. (JINF. 05, A., 49 anos).

28- Lugá rodiado de água onde fica as canoa (INF. 23, J.M., 30 anos).

Quadro 2 - MARÉ É CONTAINER

A Maré é conhecida por todos e, na língua comum, ela é nomeada por meio de expressões prototípicas. Porém, na comunidade de Baiacu, a sua categorização é apreendida cognitivamente de uma forma especial, em decorrência da atividade pesqueira realizada, diariamente, para garantir o sustento dos pescadores, da sua família e amigos, assim como do comércio do produto do seu trabalho.

A Maré é percebida por meio da metáfora conceptual MARÉ É CONTAINER. Ela é categorizada como um objeto que possui medidas de comprimento, altura (ela pode ser alta ou baixa, rasa ou funda); tem limites: bordas, meio, superfície, altura, comprimento, largura, entrada, saída; dentro dela há, além do líquido do qual é constituída (água), peixes, camarões, siris, mariscos, homens, embarcações. O domínio conceitual é experienciado em termos de região limitada, com superfície, um container. Como região limitada, o esquema de container é ativado na Maré e, de acordo com a concepção do pescador, a Maré é afetada ou controlada pelas condições impostas na forma em que ela se encontra inserida. A metáfora MARÉ É CONTAINER é uma metáfora ontológica, em que a Maré é vista como ser animado, além de ter como função a de se tornar grande receptáculo para acondicionar algo. O conceito Maré, cujo sentido físico é 'movimento periódico das águas do mar em relação a uma referência fixa no solo', apresenta acepções metonímicas e metafóricas que fazem dele um esquema de container (como nos exemplos do quadro 2). 
É assim que, por meio dos exemplos usados na linguagem cotidiana, delimita-se o cenário da MARÉ, onde se percebem metáforas e metonímias diversas. As extensões metonímicas aplicam-se de certo modo ao centro ou núcleo de um organismo.

Há de se assinalar o grau de metaforicidade da unidade conceitual "fundo", que aparece em vários contextos no corpus de As metáforas da Maré, com aspecto semântico de positivo, porque representa quase sempre certeza de boa pescaria, ou estar em alto mar, e quando a rede alcança a parte das profundezas do mar. É muito saliente no exemplo 26 do Quadro 2, para representar o caráter orientacional, fazendo-se reconhecer enquanto expressão polissêmica:

[...] antes, não usava nada no má, pra não dá azá e espantá o pexi, que fica na ponta da coroa ou no fundo da maré. Mas, oje, usa sapato, por isso não tem pexi (INF. 05, J.A., 49 anos);

Pode igualmente relacionar-se com o todo pela parte (água por mar)

(Quadro 2, exemplos 7, 13, 14, 16, 22, 28)

(7) [...] E tem lugá, tem tipo de pexi, por exemplo, que ele vê o pexi em cima d'água, cerca o pexi, o mermo pexi, qué dizé, vê o vêtíju do pexi nas água, [...] (INF. 04, O.C., 72 anos);

(13) E dai ahenti comecemu na maré, [...] os mosu que fica co'a água nos peitu [...] o mosu que água fica по јиеди ои аbаxо do јиеди (INF. 02, C. P .N. 66 anos).

(14) [...] Os de lá vai, vai com água na cintura, nas caxa dos peitus, e os daqui vai pelo razu, é calãw di terra [...] (INF. 04, O. C., 72 anos).

(16) [...] se eu não tivé uma cuia não pode disgotá a canoa, não pode tirá a água de dent'da canoa [...] (INF. 01, M. D. 68 anos).

(22) De dentro do barco largamo a redi e deixamo ela mesma trabaiá, ficá flutuano na água ((INF. 03, J. A. G. 59 anos).

(28) Lugá rodiado de água onde fica as canoa (INF. 23, J.M., 30 anos).

A exploração da metáfora segue essencialmente por vias metonímicas: do container ao conteúdo. O container pode ser tomado pelo seu conteúdo, remetendo nomeadamente para os apetrechos e os pescados que a Maré pode conter (exemplo: o fato de ter alguma coisa sobre a Maré ou colocar algo sobre essa superfície). Por outro lado, não é um simples receptáculo, mas um container, como centro de funcionamento de seus produtos. Quer com isso dizer que o conceito Maré se desloca para manifestações sensoriais e motoras que dele emanam.

De acordo com o sentido prototípico, Maré significa, para os pescadores de Baiacu, inicialmente, uma metáfora em função de zonas territoriais. Maré recebe o sentido de um conceito metafórico correspondente ao fato de as substâncias serem vistas como recipientes, e estende-se por via metonímica à substância 
e à gradualidade. Isso deu origem às extensões metafóricas nomeadamente encontradas em exemplos do Quadro 2. É uma demarcação natural física do nível do mar, de tal forma que ele tem um interior e uma superfície delimitada. Faz parte da metáfora do container em que se projetam as zonas territoriais, i.e., objetos com um dentro e um fora, além dos limites impostos como em cima, na beira, na beirada, no alto e da sua completude, como toda chea:

(Quadro 2, exemplos 1, 2, 3, 4, 15, 17)

(1) Antes a maré ia até lá em cima, na rua. Oje, vai apenas até o cais (INF.16, A.S.M., 64 anos).

(2) [...] coloca pra secá aqui e coloca lá no meio do má [...] (INF. 07, L.A.S., 34 anos).

(3) [...] saí com a redi pro fundo, procurá o marisco. [...] Um só di terra, o que vão por terra, na berada da maré [...] (INF. 09, A.F.P.C., 41 anos).

(4) Pesqueru, ahenti vai no mato, corta vários pau, dexa secano na bera da maré [...] (INF. 13, M.O.L., 22 anos).

(15) [...] quando a maré tá toda chea, merguio e boto um cãbitu numa parte [...] (INF. 05, J. A. 49 anos).

(17) [...] de longe você vê, po tá lá no arto mar [...] (INF. 03, .J. A. G. 59 anos).

Com isso, é viável assinalar o que assegura Vilela “[...] a própria conceptualização do que vemos é feita em termos de campo visual e, portanto, de container" (VILELA, 1996, p. 332).

Nessas projeções para Maré, está, ainda, presente outra projeção que é a que existe entre o domínio do mar e da quantidade. A quantidade é realizada pelas expressões "maré vazante"; "maré cheia”; "maré de enchente". Por um lado, significa a ausência de água; por outro, a presença de água. Traz consigo a ideia de grandes e pequenas quantidades passageiras ou cíclicas, mas o mais importante para o pescador é a possibilidade e a época de realização da pesca.

(Quadro 2, exemplos 5, 6, 15, 27)

5 - [...] largava a redi quando a maré tava toda cheia, aí o mestri com os mosu suspendia [...] Depois que suspendesse todo, dexava a maré secá [...] (INF. 05, J.A., 49 anos).

6 - [...] tirava a redi quando a maré tava toda cheia istendia e aí era a cãboa [...] Já a taĩera de ressa, você larga, a maré tá vazano[...] (INF. 05, J.A., 49 anos).

15 - [...] quando a maré tá toda chea, merguגo e boto um cãbitu numa parte [...] (INF. 05, J. A. 49 anos).

27 - A ora da pesca, depende da maré alta, baixa, seca, enchente, que puxa pra terra, vazante, que vai pra fora. (JINF. 05, A., 49 anos). 
Considerando os MCIs de Maré, encontram-se ainda modelos como: MARÉ É EMPRESA; MARÉ É TEMPO; MARÉ É SER ANIMADO; MARÉ É OBJETO; MARÉ É ASTRO/LUA; MARÉ É CAMINHO; MARÉ É DÁDIVA DIVINA, SAGRADA. ${ }^{2}$

Quer dizer, a Maré é a empresa na qual os pescadores trabalham; é um ser com qualidades (merece respeito, é boa, brava, tardeira, cedeira, determina o tempo de trabalho); cresce ou não cresce, morre; é um objeto que pertence aos pescadores; pode quebrar; é um livro, no qual os pescadores encontram lições de vida; é um astro, um planeta; é um caminho por onde se dirigem os pescadores para a sua labuta diária; é misteriosa, oculta segredos e veneração (sagrada), exige respeito. Há que se registrar, também, a ocorrência de expressões idiomáticas, como "cabeça d'água" e "a maré não tá pra peixe".

\section{CONCLUSÃO}

Diante do exposto, realismo corporificado não significa subjetivismo extremo, representação cerebral, mas a preocupação com a filiação epistemológica empírica, a corporeidade como corpo no mundo, experiencialista, a "filosofia na carne". Ao argumentarem que, em muitos domínios da experiência, as metáforas são a única possibilidade que se tem de comunicar conhecimentos, Lakoff e Johnson (1980/2002) têm dedicado atenção especial à metáfora como fonte e veículo da reconstrução da realidade cotidiana. Tais autores explicitam a onipresença da metáfora ao sistematizar inúmeros exemplos do falar habitual. Por conseguinte, Lakoff e Johnson (1980/2002) asseguram que o importante, quando se trata de um fenômeno dentro de uma área de estudo, é olhar além das fronteiras da própria cultura, a fim de o investigador descobrir mares que podem ser navegados, arriscarse a uma nova perspectiva desconhecida.

A abordagem cognitiva da metáfora presente nos conceitos proeiro, mestre, cabeça permite perceber a iluência das dimensões corporais, sociais, culturais. E a Linguística e a Semântica Cognitivas vêm corroborar a importância deste tema e para o qual procuram identificar alguns de seus fundamentos. Para os pescadores, a metáfora decorre da instantaneidade de saber sua compreensão. Eles usam a metáfora, sabem como usá-la, mas não sabem o que é. O conceito de metáfora é compatível com modelos de categorização de experiência dos pescadores, como eles percebem o mundo, se comportam e o modo como se relacionam com o mar, os artefatos, as pessoas, as coisas e como identificam os conceitos que governam o pensamento deles, assim como suas atividades cotidianas. A atenção dos pescadores está tão ocupada com atividades laborais que, ao significado de tais expressões, somase uma especificidade, só compreensível contra o fundo de sua psicologia grupal, na vida, como em outras experiências cotidianas. Nessa perspectiva, o significado é contextual, dá coesão ao todo. Afinal, como asseguram alguns pesquisadores, as escolhas comunicativas "inconscientes" feitas pelas pessoas que trabalham no setor pesqueiro encobrem outras áreas, além da terminológica.

\footnotetext{
${ }^{2}$ Discutidos durante encontro de orientação.
} 
Os resultados apontam que os principais fatores culturais encontrados na pesca para explicar a metáfora são: diferentes protótipos para a percepção dos objetos; acumulação de conhecimento relevante sobre a pesca, o mar, os artefatos, os tipos de pescaria, entre outros. As decorrências encontradas neste estudo corroboram as de Lakoff e Johnson (1980/2002) ao assinalarem que, nas metáforas estruturais, é possível fazer uso de expressões de um determinado domínio para falar de conceitos correspondentes no domínio definido metaforicamente. Neste estudo, constatou-se ainda que as semelhanças existentes entre fonte e alvo não têm que ser reconhecidas conscientemente pelos falantes. Mas a semelhança entre os dois domínios é preexistente. Como preconizam Lakoff e Johnson (1980/2002), a metáfora acaba, portanto, por definir o que é real para uma dada cultura informando uma visão de mundo particular, em que conceitos metaforicamente estruturados orientam a percepção das ações.

Conforme demonstram os dados, a percepção que os pescadores têm da metáfora é frequentemente a compreensão de um significado qualitativo e de referência espacial. Alguns conceitos emergem diretamente desta percepção, por exemplo,PARACIMA; e outros emergemmetaforicamentebaseados na experiência, exemplos PROEIRO; CABEÇA. Consequentemente, a TMC continuará com as questões de como os conceitos são associados convencionalmente com cada outro conceito, mas investigará como e porque as associações são convencionais, e como os mapeamentos entre domínios são estruturados. Esses argumentos são centrais para a compreensão da metáfora e de importante implicação para aqueles que buscam entender a teoria da metáfora e mais especificamente o modelo da metáfora conceptual. E é assim que, naturalmente, essa é uma pesquisa inconclusa, ainda existem "pensamentos verdes" a serem trabalhados, questionados e traduzidos. Recorrendo à linguagem dos pescadores "ainda há muitos peixes a serem fisgados nesta rede", isto é," o mar está para peixe".

Assim, o presente trabalho sugere um mergulho mais profundo quando se trata de problemas que afloram na abordagem dos estudos da metáfora conceptual, quando se trata de estudos cognitivos. Se quiser, pois, compreender a dimensão empírica aliada à análise cognitiva um trabalho que se permite entrever o universal dentro do particular e que pode ser comparado à natureza complexa da metáfora. É, por conseguinte, capaz de contribuir para os estudos científicos da metáfora desenvolvidos pelos linguistas cognitivistas.

\section{REFERÊNCIAS BIBLIOGRÁFICAS}

ALVES, Iêda Maria (Org.). A constituição da normalização terminológica no Brasil. Cadernos de Terminologia, São Paulo, n.1, FFLCH/CITRAT, 1996.

ALVES, Iêda Maria. A delimitação da unidade lexical nas línguas de especialidade. In: Neologia técnico-científica na imprensa brasileira contemporânea. In: Actas de RITERM- VII Simpósio. São Paulo, 2010.

BATORÉO, H. J. Expressão do espaço no português europeu: contributo psicolinguístico para o estudo da linguagem e cognição. Portugal: Fundação Calouste Gulbenkian. 930 p . 1997. 
DELBECQUE, Nicole. A base cognitiva da linguagem: língua e pensamento. In: _. A linguística cognitiva : compreender como funciona a linguagem. Lisboa: Instituto Piaget, pp.17-48, 2006.

DIAS NETO, José Colaço. Quanto custa ser pescador artesanal? Etnografia, relato e comparação entre dois povoados pesqueiros no Brasil e em Portugal (2012). 337 f. Tese (Doutorado em Antropologia). Universidade Federal Fluminense, Instituto de Ciências Humanas e Filosofia, Programa de Pós-Graduação em Antropologia, Niterói, 2012. Disponível em:<www.proppi.uff. br/ppga/sites/default/.../tese_versao_final-jose_colaco.pdf> Acesso em: 20 nov. 2013.

FARIAS, Emília Maria Peixoto; Lima, Paula Lenz Costa Lima. Metaphor and foreign language teaching. In: D.E.L.T.A. Revista de Documentação de Estudos em Linguística Teórica e Aplicada.v.26, $\mathrm{n}^{\circ}$ especial, 2010. Metaphor and Cognition (Metáfora e Cognição). ISSN 0102-445. São Paulo: Editora EDUC, Editora da PUC São Paulo, pp. 453-478.

FAULSTICH, Enide. Base metodológica para pesquisa em socioterminologia. Brasília: LIV/UNB, $1995 ; 2002$.

FERRARI, Lilian. Introdução à linguística cognitiva. São Paulo: Contexto, 2016.

FINATTO, Maria José Bocorny. Reconhecimento da metaforização em linguagens técnicas e científicas: desafios e perspectivas. In: Organon, Metáfora em perspectiva, n. 43, Revista do Instituto de Letras da Universidade Federal do Rio Grande do Sul. v.21 n. 43; 2007, pp.119-127, ISSN 0102-6267.

GONZALEZ-MARQUEZ, Mônica et al. (Org.). Methods in cognitive linguistics. Amsterdam/ Philadelphia: John Benjamin Publishing Company, 2007.

GRADY, J. Foundations of meaning: primary metaphors and primary scenes. University of California, Berkeley: Ph.D. Dissertation, 1997.

GRUPO PRAGGLEJAZ.. PIM: um método para identificar palavras usadas metaforicamente no discurso. Trad. Dalby Dienstbach Hubert. In: Cadernos de Tradução: Linguística Cognitiva. Maity Siqueira (Org.). n. 25,jul/dez-2009 Revista do Instituto de Letras da Universidade Federal do Rio Grande do Sul. $2^{a}$ reimpressão, n. 25; 2009, pp.77-120, ISSN 1807-9873, 2004.

KRIEGER, Maria da Graça; Finatto, Maria J. B.. Introdução à terminologia: teoria e prática. São Paulo: Contexto, 2004.

LAKOFF, G.; JOHNSON, M. Metaphors we live by. Chicago: Chicago University Press, 242 p., 1980.

LAKOFF, G.; JOHNSON, M. Metáforas da vida cotidiana. Trad. Grupo de estudos da indeterminação e da metáfora (GEIM) sob coord. de Mara Sophia Zanotto e Vera Maluf. Campinas: Mercado de Letras: Educ. p. 254, 2002 (Original publicado em 1980).

MATEUS, Maria H. M; Correia, Margarita (Coord.). Terminologia: questões teóricas, métodos e projectos. Comissão Nacional para as comemorações dos descobrimentos portugueses. Ed. Francisco Lyon de Castro. Portugal: Publicações Europa-América, jul., nº 04, pp. 10-12; 19-44, 1998.

MEIRELLES, Maria das Graças Correia. O peixe nosso de cada dia: etnografia do sistema pesqueiro em Baiacu. (Tese de Doutorado). Programa multidisciplinar de Pós-Graduação em cultura e sociedade- UFBA-FACOM, Salvador, ag. 2011.

MORAES SILVA, Antonio de (1813). Diccionario da língua portugueza. Lisboa: Typographia Lacerdina, 1813. Disponível em:<http://www.ieb.usp.br/online/>. Acesso em: 30 jan.2012. 
MOREIRA, Cristiane Fernandes. As denominações para os pescadores e os apetrechos de pesca na comunidade de Baiacu/Vera Cruz/Ba. 384 f.:il Inclui anexos. Dissertação (Mestrado em Letras e Linguística. Área de Concentração: Linguística Histórica) - Instituto de Letras, Universidade Federal da Bahia, São Paulo, Salvador, 2010.

PELOSI, Ana Cristina. Metáfora e empatia no discurso sobre violência urbana em Fortaleza, Ceará, Brasil. (Mesa-redonda). In: IV Congresso Internacional sobre Metáfora na linguagem e no pensamento, 2011, Programação. Porto Alegre: Universidade Federal do Rio Grande do Sul, Out. 2011; 2012.

RIBEIRO, João Ubaldo. Viva o povo brasileiro: romance. 21 ed. Rio de Janeiro: Nova Fronteira, 1984.

ROSCH, E.. Cognition and Categorization. New Jersey: Lawrence Erlbaum Associates, Hillsdale, 1975.

SCHRÖEDER, Ulrike. Os precursores filosóficos da teoria cognitiva das metáforas. Cadernos de estudos linguísticos. Universidade Estadual de Campinas, v 2, n 46, pp. 243-252, 2004 b.

SILVA, Augusto Soares da. Protótipos, metáforas e frames: novas tendências da semântica cognitiva como modelo maximalista e contextualizante do significado (Conferência). In: $60^{\circ}$ Seminário do GEL (Grupo de estudos linguísticos de São Paulo). Universidade de São Paulo-Campus Butantã: São Paulo,04,05, 06 de julho de 2012.

SIQUEIRA, Maity et al. Identificação de metáforas em uma obra terminográfica: definição de critérios e análise de casos. In: Organon, Metáfora em perspectiva, n. 43, Revista do Instituto de Letras da Universidade Federal do Rio Grande do Sul. v.21 n. 43; 2007, pp.181-195, ISSN 0102-6267.

TEMMERMAN, Rita R. Towards news ways of terminology description: the sociocognitive approach. Amsterdam/Philaddelphia: John Benjamins Publishing Company, 2000.

TEMMERMAN, Rita R. Modelos metafóricos e a postura do tradutor frente a textos científicos. Trad. Danilo Nogueira Marra. In: Cadernos de Tradução: Linguística Cognitiva. Maity Siqueira (Org.). n. 25,jul/dez-2009 Revista do Instituto de Letras da Universidade Federal do Rio Grande do Sul. $2^{a}$ reimpressão, n. 25; 2009, pp.217-234, ISSN 1807-9873.

TEIXEIRA, José de Sousa. Metaphors, We Li(v)e By: Metáfora, verdade e mentira nas línguas naturais. In: Revista Galega de Filoloxía, n 14/2013, Universidade da Corunha (Espanha), pp.201-225, 2013.

TEIXEIRA, José de Sousa. A Bolsa e a vida: Sistematicidade e metaftonímia no discurso económico. In: Revista Galega de Filoloxía, no 14/2014, Universidade da Corunha (Espanha), p. 397-412, 2014.

VELASCO, Ideval da Silva (2004). Terminologia da pesca em Soure-Marajó: uma perspectiva socioterminológica. 2004. v 1, 101 f. Dissertação (Mestrado em Letras: Linguística e Teoria Literária), Programa de Pós em Letras: Linguística e Teoria literária. Universidade Federal do Pará, 2004.

VEREZA, Solange Coelho. Articulating the conceptual and the discursive dimensions of figurative language in argumentative texts. D.E.L.T.A. Revista de Documentação de Estudos em Linguística Teórica e Aplicada. n especial, 2010. Metaphor and Cognition (Metáfora e Cognição). São Paulo, v26, pp.701-718, 2010.

VILELA, Mário. A metáfora na instauração da linguagem: teoria e aplicação. Revista da Faculdade de Letras, Linguas e Literaturas. Porto, XIII, pp.317-356, 1996.

ZANOTTO, Mara Sophia. Modelos culturais e indeterminação metafórica. Organon, Metáfora em perspectiva, n 43, Revista do Instituto de Letras da Universidade Federal do Rio Grande do Sul. v21 n 43, pp.97-118, 2007. 
Agradecimentos à CAPES, pela Bolsa Sandwich, Programa de Doutoramento Sandwich no Exterior-PDSE, processo $\mathrm{N}^{\circ} 1249112-8$; às Instituições Universidade Federal da Bahia-UFBA e a UMinho-Universidade do Minho-Campus GualtarPortugal. 